\title{
大都市沿岸域における用途地域指定と 土地利用クラスターの空間的関係性に関する研究 A STUDY REGARDING SPATIAL RELATIONSHIP BETWEEN OFFICIALLY
DESIGNATED LAND CLUSTERS AND ACTUAL LAND USE CLUSTERS IN
METROPOLITAN COASTAL AREAS
}

宮崎隆昌*, 横 堀純子**, 菅 雅 幸***, 中澤公伯**** Takamasa MIYAZAKI, Sumiko YOKOBORI, Masayuki SUGA and Kiminori NAKAZAWA

\begin{abstract}
This study aims at grasping the relationship between officially designated land (ODL) and actual land use (ALU) in the Metropolitan coastal areas. The relationship varies significantly between shore side areas and inland areas. We examined, using overlaid mesh data, the disagreement of the relations between the distance from the waterfront and officially designated land clusters, between types of officially designated land and actual land use clusters, and between officially designated landclusters and actual land use clusters. With the examined data, we investigated the cause of the disagreement.

The investigation has revealed:1 Both actual land use clusters and officially designated land clusters are greater in shore side areas. We explored the characteristics of land use structure in the coastal areas and methods of creating suitable plans and their possibility, by verifying. 2 The characteristics of actual land use clusters according to the types of officially designated land. 3 The characteristics of actual land use cluster that is caused by changing officially designated land clusters.
\end{abstract}

Keywords : Actual Land Use, Officially Designated Land, Clusters, Coastal Zone, Geographic Information System 土地利用、用途地域、クラスター、治岸域、地理情報システム

1. はじめに

\section{1-1. 研究の背固と目的}

大都市の臨海部と内陸部では、土地利用上の環境特性が著しく異なつ ており、臨海部では未利用埋立地や工場跡地が遊休化するなどの諸問題 が健在化している。著者らはこれまで、この原因の一つを土地利用配置 パターンの相違とし、この問題に関する臨海部と内陸部における現状を 示してきた 121314)。大都市沿岸域臨海部の土地利用は、産業・物流中心 であるため同用途土地利用のまとまり度合いが高いことから、宮崎ら （2003）は、大都市沿岸域における土地利用配置パターンの把握を、同 用途土地利用のまとまりー土地利用クラスターの側面から行った。本報 はこれに引き続き、土地利用クラスターに影響を与える地域地区用途地 域制との関係について触れ、相互の関係性を把握することを目的とする。

\section{1-2. 既往研究}

.土地利用配置パターンに関する研究には、小出 5、玉川 6 15)、青木 フ 899)、文 ${ }^{10}$ 、恒川ら 11、竹内ら 12、吉川ら 13141818小林ら 1017、飯塚ら 19) の研究があり、今後もこの種の研究の展開が期待されている。この中で、 同用途土地利用のまとまりの度合いに関する研究には、玉川 (1982)、恒 川ら（1991）のものがあり、玉川（1982）は、土地利用メッシュデータ において、同種用途のセルが辺を共有する場合それらをまとめて、1つ のまとまりをつくりこれをClump と称して土地利用の秩序性を表現して
いる。これらは土地利用混合度の把握手法に関する研究の一種であり、 竹内ら（1994）は、用途を 1 種類に特定して、その用途についての「一 体的面積」あるいは「まとまり」を示すのに適しているとしている。ま た、浸透理論（パーコレーション）の分野においても同一物質のまとま り=クラスターに関する理論が応用されている。しかし、本研究のよう に、土地利用の指定と実態の両面からアプローチしたものは少ない。

\section{1-3 研究の展開方法}

本研究においては、玉川 (1982)、恒川ら（1991）と同様に、同用途土 地利用のまとまりをメッシュデータ上において縦横の同用途が連続して いることとして、クラスターを定義して研究を進める。本稿の前半部分 では、クラスターの算定手法と土地利用・用途地域の各クラスターの基 本的特性を述べる。後半部分では、土地利用クラスターを規定する要素 を用途地域指定の種別と用途地域クラスターの大きさと仮定し、用途地 域の用途種別による土地利用クラスターの大きさの変動、用途地域の大 きさの違いによる土地利用クラスターの大きさの変動の把握を行う。

\section{2. 方法}

\section{2-1. 研究対象領域とメッシュデータ}

対象領域として、東京湾沿岸域を取り上げる。Fig. 1 に示すように、 京浜工業地帯と京葉臨海工業地域を含む神奈川県横浜市八景島付近から

\footnotetext{
* 日本大学生産工学部建築工学科 教授·工博

** 日本大学大学院生産工学研究科 大学院生

*** 日本文理大学工学部建築学科 助教授・工修

**** (珠環境形成研究所 主任研究員・博士 (工学)
}

Prof., Dept. of Arch., College of Industrial Technology, Nihon Univ., Dr. Eng. Graduate Student, Graduate School of Industrial Technology, Nihon Univ.

Assoc. Prof., Dept. of Arch., College of Engineering, Nihon Bunri Univ., M. Eng. Chief Research Engineer, Environmental Optimization Laboratory, Ltd., Dr. Eng. 


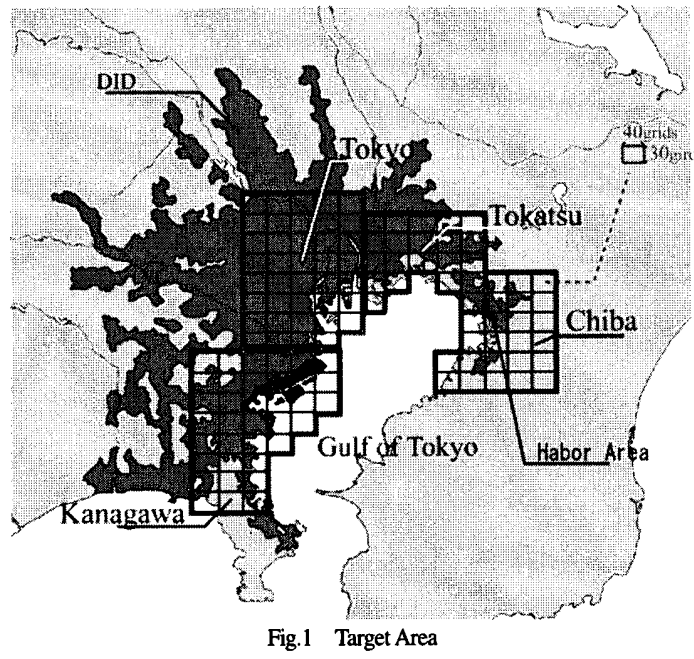

千葉県市原市まで、海岸線との奥行き方向には海岸線から約 $5 \mathrm{~km} \sim 10 \mathrm{~km}$ とする。同研究対象領域の著者らの既往研究 ${ }^{2)}$ によると、本研究対象領 域においては海岸線より $1,000 \mathrm{~m} \sim 2,000 \mathrm{~m}$ の間領域を境に、空間特性 が臨海性の地域之内陸性の地域に乘離する傾向にあり、海岸線から奥行 き方向 $5 \mathrm{~km}$ 以内には海面、埋立地、内陸部と異なる機能を有した臨海部 がほとんど含まれているといえる。また、桜井ら（1988）が述べるよう に、都市と港湾との間には曖昧な性格の地域 - グレーゾーン - が存在し ており、埋立地と非埋立地の境界で明確に環境特性が異なるとは限らな い。海岸線から奥行き方向でみる視点（臨水界距離で見る視点）は沿岸 域を捉える上で不可欠であり、対象領域は内陸との関係性も把握できる よう包括的なものとした。

分析には、以上の領域に該当する細密数值情報（10mメッシュ土地利 用 1984 年・1994 年、 $100 \mathrm{~m}$ メッシュ用途地域注 1994 年) をそれぞれ使 用する。

ポリゴンデータを使用する手法もある ${ }^{21)}$ がここでは、メッシュデータ を使用することにより、臨海部から内陸部にかけて連担するクラスター の大きさを微小地域ごと個々に把握でき、本研究の着眼点である海岸線 からの距離（臨水界距離）ごとの把握を容易にすることができる。

\section{2-2. 土地利用現況}

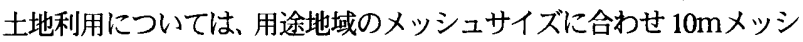
工 100 個（10 個 $\times 10$ 個）ごとに、優先属性（最大面積をしめる属性） によって代表させる優先属性法により $100 \mathrm{~m}$ メッシュに変換し、さらに 既存の 17 分類を 10 分類注 2 に統合し、水域・データなしを除く 8 分類を

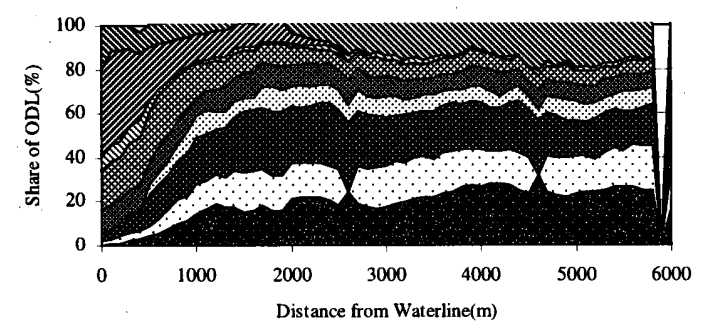

- EDR1 DEDR2 I RD ENCD a CD Q

Fig.2 Share of ODL and Distance from Waterline

(Category 1 Exclusive District for Residential use: EDR1, Category 2 Exclusive District for Residential use: EDR2, Residential District: RD, Neighborhood Commercial District: NCD, Commercial District: CD, Light - Industrial District: LID; Industrial District: ID, Exclusive District for Industrial use: EDI, Urbanization Control Area: UCA)

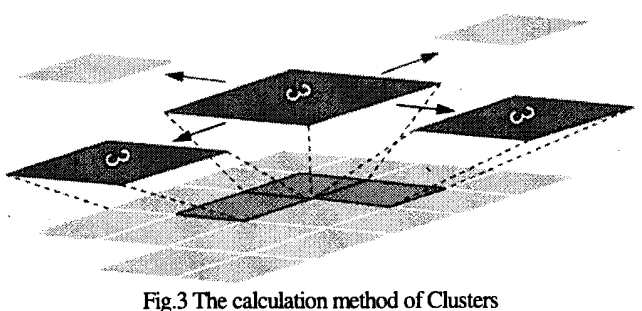

使用する。研究対象範囲における土地利用用途の数は、1994 年では、工 業用地・9,728 メッシュ（7\%）商業用地・12,643 メッシュ（9\%），農 業用地・29,649 メッシュ (22\%) オープンスペース・16,283 メッシュ （12\%）公共用地・12,458 メッシュ（9\%） 住宅用地・46,434 メッシ ユ（34\%） その他・9,696メッシュ（7\%）であった。1984 年では、工 業用地・10,247 メッシュ（7\%） 商業用地・10,150 メッシュ（7\%） 農 業用地・40,290 メッシュ (28\%) オープンスペース・20,910 メッシュ （14\%） 公共用地・11,151 メッシュ（8\%） 住宅用地・42,812 メッシ ュ（30\%） その他・9,241 メッシュ（6\%）であった。

\section{2-3. 用途地域}

安在ら（1998）が指摘するように、臨海部の臨港地区指定地域では分 区による用途規制が優先されるが、本研究では対象領域を内陸部にまで 広げている点（Fig.1）、東京湾沿岸域に指定されている臨港地区はアイ ランド型埋立地が大多数を占め、その周辺との実益的関わりは少ない点 から、臨港地区分区は対象外とし、用途地域制のみを研究対象とした。

デー夕は、研究対象地域に該当する、100mメッシュに変換された市販 の 1994 年度用途地域メッシュデー夕を使用した。研究対象領域における 用途地域の指定状況は、第一種住居専用地域・18,089 メッシュ（15\%） 第二種住居専用地域・17,472 メッシュ（15\%）住居地域・20,429 メッ シュ (16\%) 近隣商業地域・10,341 メッシュ (9\%) 商業地域・9,461 メッシュ (8\%) 準工業地域・11,227 メッシュ $(10 \%)$ 工業地域・4,438 メッシュ（4\%） 工業専用地域・7,988 メッシュ（7\%） 市街化調整区 域・18,503 メッシュ（16\%）であった。

海域からの距離（臨水界距離）別にみると Fig.2 のように、第一種住 居専用地域、第二種住居専用地域、住居地域及び市街化調整地域は、臨 海部ほど少なく、内陸部ほど多い。また、準工業地域、商業地域及び近 隣商業地域は、臨海部と内陸部とで用途地域の数に差はみられない。

\section{2-4. クラスター算定方法}

本研究では、Fig.3に示すように、対象メッシュの同一の土地利用用途 で、対象メッシュの上下、左右に隣接するメッシュを同クラスターとす ることにして算定を進める。この場合、斜め位置に隣接するメッシュは 同クラスターと見なさないため、メッシュ化前の “実際の”クラスター 注 3 を正確に示さない場合がある。以下の手順により用途地域及び土地利 用クラスターの算定を行う。

(1)用途地域現況及び土地利用現況の用地・用途ごとのレイヤー化 用途地域現況メッシュデータマップを各用途地域ごと（第一種住居専 用地域 - 第二種住居専用地域 - 住居地域 - 近隣商業地域 - 商業地域 - 準 工業地域・工業地域・工業専用地域・地域指定なし・市街化調整区域・ 計画区域外)、各土地利用用途ごと（工業用地・商業用地・農業用地・才 ープンスペース・公共用地・住宅用地・その他）のメッシュデータマッ プに分解（レイヤー化）を行う。 (2)用途地域・土地利用クラスター数のカウント 各地域において、同用途地域・同用途のクラスターの数をカウントする。 


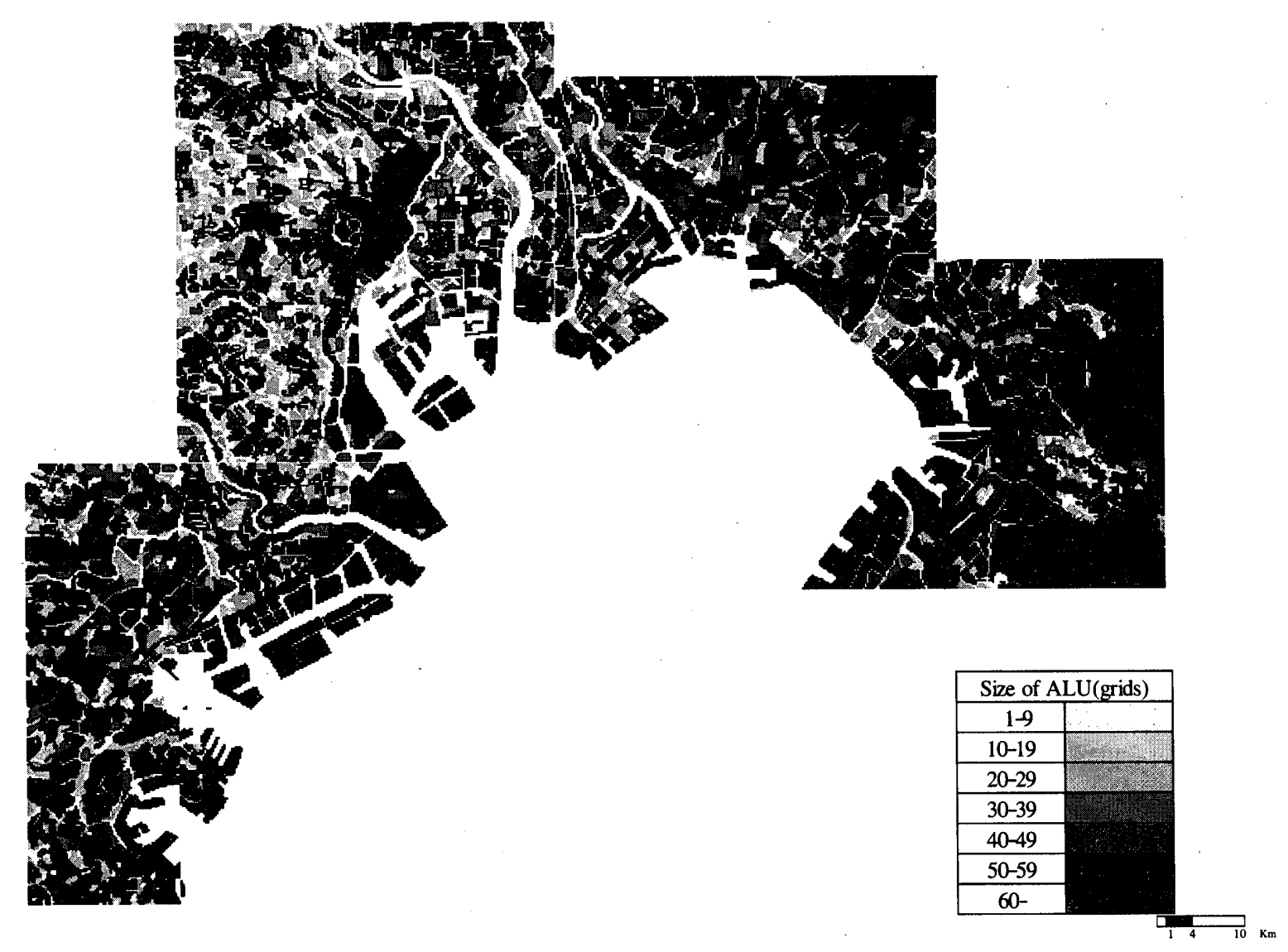

Fig.4 Actual Land Use Clusters Grid Data Map (1994)
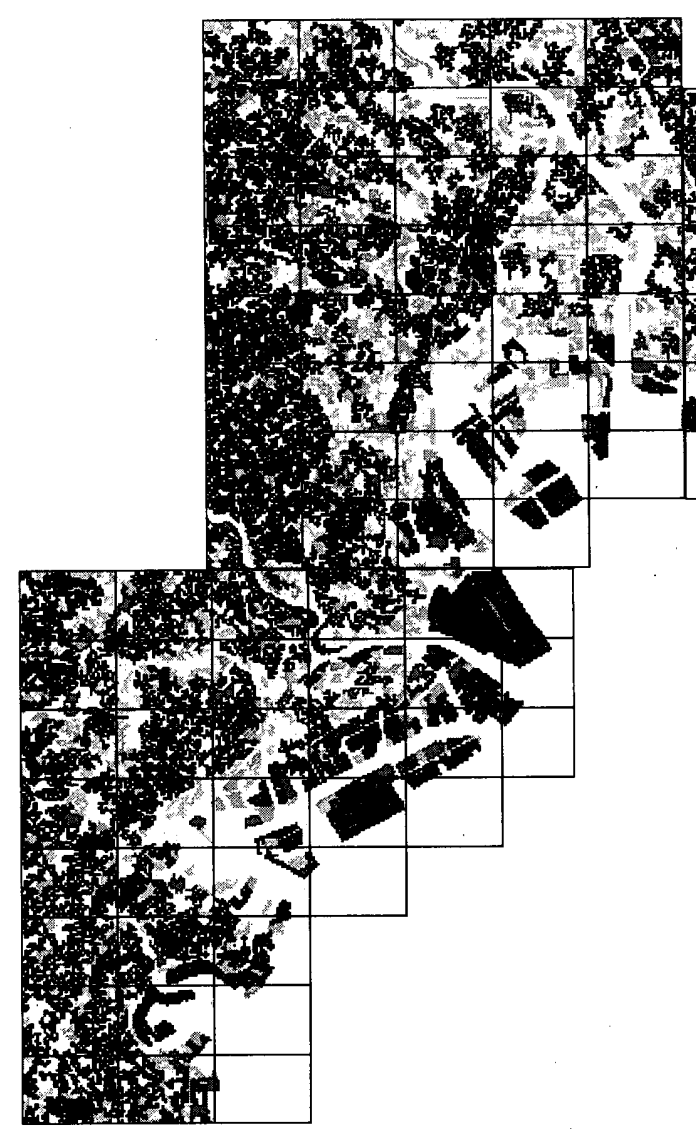

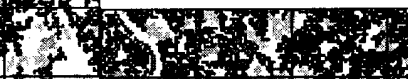

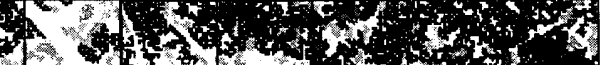

$\checkmark(5,2)$

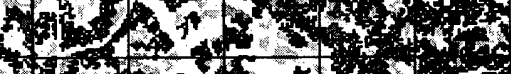

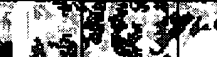

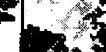
$\rightarrow+2,1$,

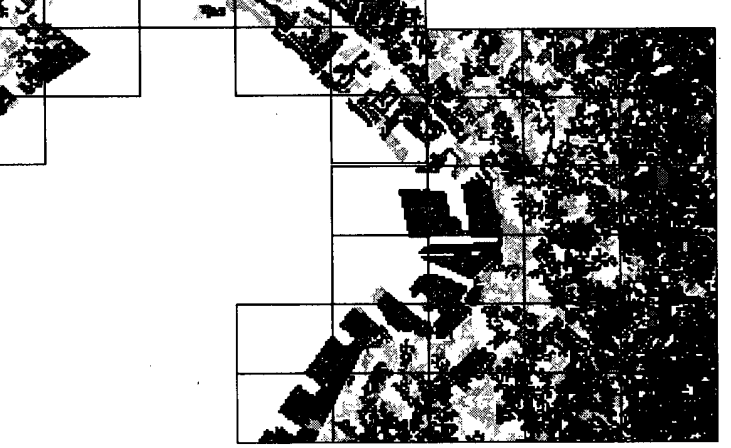

\begin{tabular}{|c|}
\hline \multicolumn{2}{|c|}{ Size of ODL(grids) } \\
\hline $1-9$ \\
\hline $10-19$ \\
\hline $20-29$ \\
\hline $30-39$ \\
\hline $40-49$ \\
\hline $50-59$ \\
\hline $60-$ \\
\hline
\end{tabular}

Fig.5 Officially Designated Land Clusters Grid Data Map 
(3)各用途地域・各土地利用クラスターの大きさの算定

各クラスターにおけるクラスターの大きさ（メッシュ数）を求め、各メ ッシュにその値を記入する。

(4)平均化

各地域ごとに各地域地区用途地域・各土地利用用途におけるクラス ターの大きさの平均を算出する。

\section{3. クラスター算定結果}

\section{3-1 土地利用クラスター}

Fig.4 は、全ての用途の土地利用クラスターの大きさを濃淡でメッシ ュごと示したメッシュデータマップである。臨海部と臨水界距離 $10 \mathrm{~km}$ 以上の内陸部で大クラスターを含むメッシュが目立つことが把握でき る。

1994 年の各土地利用クラスター (全 20,633 クラスター) の大きさの 平均は、工業用地：7.9 メッシュ、商業用地： 3.8 メッシュ、農業用 地：18.0メッシュ、オープンスペース: 4.4 メッシュ、公共用地： 3.8 メッシュ、住宅用地：15.1 メッシュ、その他 : 2.2 メッシュであった。 宮崎 (2003) らは、これと 1984 年のデータとオーバーレイした結果、 土地利用クラスターは小規模化・多数化の傾向にあり、特に大規模な ものが多い臨海部で影著であるとしている。工業用地、オープンスペ 一ス、公共用地の各クラスターは、臨海部で大きく、内陸部で小さい。 逆に、商業用地、農業用地、住宅用地は臨海部で小さく、内陸部で大 きい。

3-2 用途地域クラスター

Fig.5 は、土地利用クラスターと同様に、計 7,371 個の用途地域クラ スターの数え上げを行った後、各大きさを各用途ごと濃淡で示したも のである。土地利用クラスターと同様に、臨海部で大クラスターを含 むメッシュが目立つことが把握できる。

用途地域クラスター（全 7,367 クラスター) の大きさの平均は、第 一種住居専用地域・ 30.7 メッシュ 第二種住居専用地域・16.6 メッシ 工 住居地域· 9.9 メッシュ 近隣商業地域· 4.0 メッシュ 商業地域・ 15.5 メッシュ 準工業地域・ 20.3 メッシュ 工業地域・23.8 メッシュ 工業専用地域・136.5 メッシュ 市街化調整区域・29.7 メッシュであつ た。土地利用クラスターと比較して、用途地域クラスターの方が大ク ラスターなものが多いが、東京都などで各用途地域における最低規模 （3ha 以上等）の規定があることも原因と考えられる。

\section{3-3 臨水界距離と用途地域クラスターの大きさ}

Fig.6-1〜 Fig.6-10 は、用途地域クラスターの大きさ及び各距離帯に おける用途地域の面積と臨水界距離との関係を示したものである。

ここで、臨水界距離による用途地域クラスター大きさの変動を以下 に類型化する。内陸に行くにつれて用途地域クラスターが大きくなる ものを Type A、内陸に行くにつれて用途地域用途地域クラスターが小 さくなるものを Type B、変化がみられないものを Type C と三種類に 分類を行った。

OTypeA : 内陸に行くにつれて用途地域クラスターが大きくなるもの 第一種住居専用地域、商業地域及び市街化調整区域は、臨海部ほど 用途地域クラスターは小さく、内陸部ほど大きい。

第一種住居占有地域及び市街化調整区域は、用途地域の数が内陸部 ほど多くなるので、これは、当然の結果だといえる。しかし、用途地 域の数が臨海部と内陸部で変化しない商業地域においては、用途地域
クラスターは内陸に行くにつれて、同メッシュ数でも結合している状態 であるといえる。

OType B : 内陸に行くにつれて用途地域クラスターが小さくなるもの 住居地域、工業専用地域、近隣商業地域、準工業地域及び工業地域は、
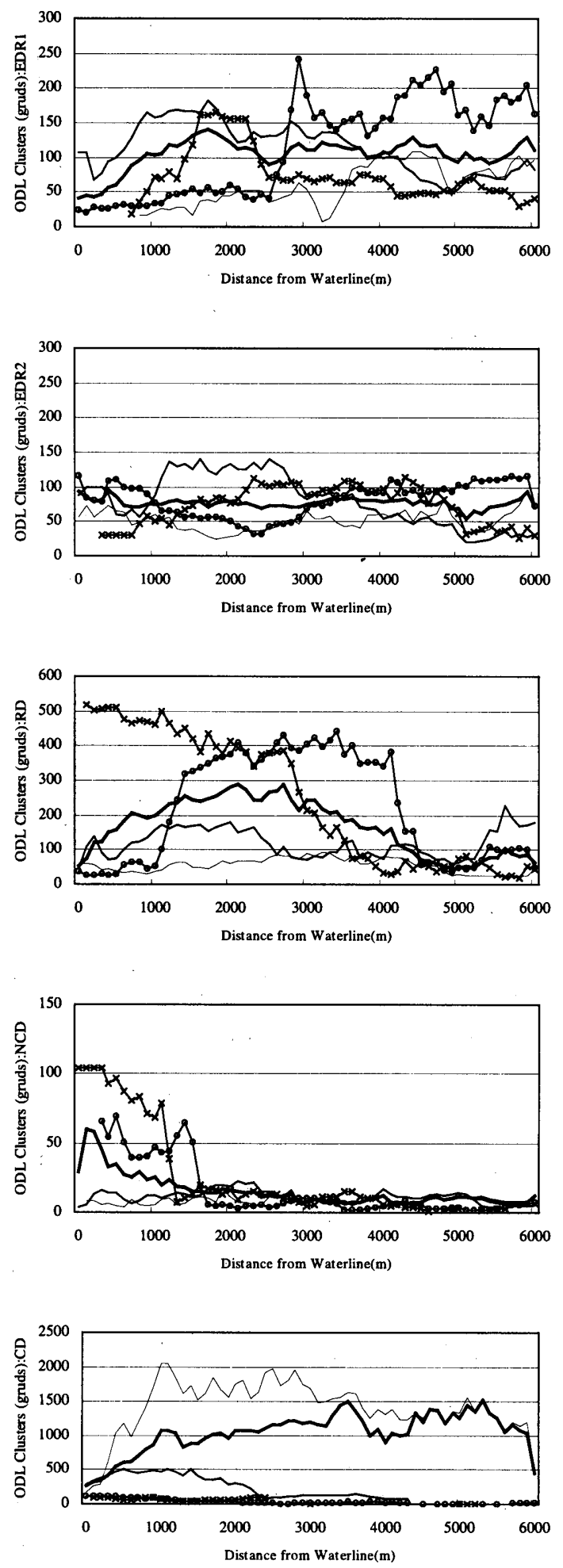

- Kanagawa - Tokyo $\rightarrow$ Tokatsu $\rightarrow$ Chiba $\longrightarrow$ Overall

Fig.6-1 Averaged Size/Area of ODL Clusters and Distance from Waterline (1) 

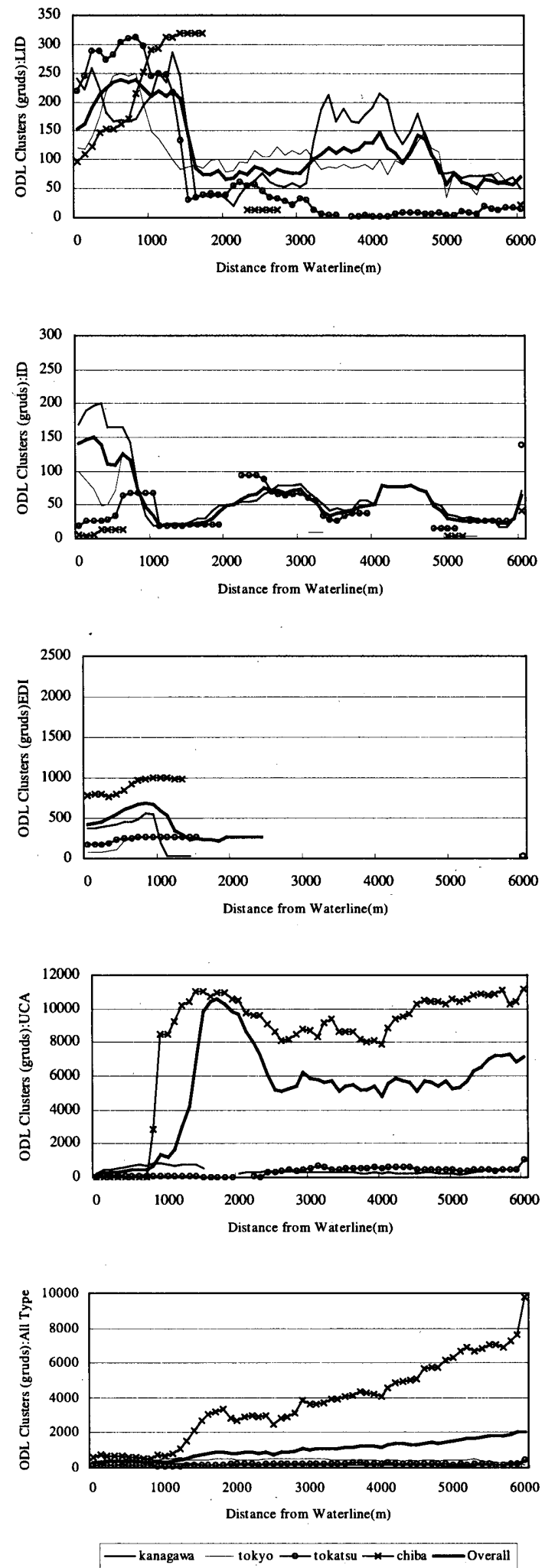

Fig.6-2 Average/Area Size of ODL Clusters and Distance from Waterline (2) (Category 1 Exclusive District for Residential use: EDR1, Category 2 Exclusive District for Residential use: EDR2, Residential District: RD, Neighborhood Commercial District: NCD, Commercial District: CD, Light - Industrial District: LID; Industrial District: ID, Exclusive District for Industrial use: EDI, Urbanization Control Area: UCA)

臨海部ほど用途地域クラスターが大きく、内陸部ほど小さい。

住居地域は、臨水界距離 $2,100 \mathrm{~m}$ まで拡大した後、縮小し、臨水界距 離 $5,300 \mathrm{~m}$ 以降 90 メッシュ付近を推移しているが、住居地域の構成比
は内陸ほど大きくなるので、内陸ほど多数化・小規模化の傾向にあると いえる。準工業地域は、臨水界距離 $800 \mathrm{~m}$ （用途地域クラスターの大き さ238.4メッシュ）から用途地域クラスターは小さくなり、臨水界距離 1,600m 以降 97 メッシュを推移する。準工業地域の構成比は臨海部之内 陸部で比較的変化しないので、用途地域クラスターは多数化・小規模化 しているといえる。また、近隣商業地域も準工業地域と同様に用途地域 クラスターは多数化・小規模化している。工業地域及び工業専用地域は、 内陸に向かうほどその構成比は小さくなるので、少数化・小規模化して いると言い換えることができる。

OType C : 変化がみられないもの

第二種住居専用地域においては、用途地域クラスター80メッシュ付近 で一定の值を取り、海域との距離的関倸はみられない。

\section{4. 用途地域と土地利用クラスターの大きさの関係}

宮崎ら（2003）は、臨水界距離 1000～2000m を境に土地利用クラスタ 一の特性が変化するとしているが、ここでは、内陸部も含んだ治岸域全 体における標準的特性としての、用途地域の種類及び用途地域クラスタ 一の大きさと土地利用クラスターの大きさとの関係性をオーバーレイ分 析により把握する。

\section{4-1. 用途地域別土地利用クラスターの大きさ}

Tab.1 は、各用途地域における全域での 1994 年及び 1984 年の土地利用 クラスターの大きさの平均值を示している。全土地利用用途のクラスタ 一の平均 (All Types) でみると、住居系の用途地域で大クラスターが多 いことが示されている。

1994 年の各土地利用現況用途における土地利用クラスターの大きさ の平均值で最大をとる用途地域は、工業用地：工業専用地域 431.5 メッシュ、商業用地：商業地域 320.1 メッシュ、農業用地：工業地域 5,275.1 メッシュ、オープンスペース用地:近隣商業地域 86.7 メッシュ、 公共用地:準工業地域 157.7 メッシュ、住宅用地:近隣商業地域 4,585.5 メッシュ、その他：工業専用地域 15.2 メッシュである。

逆に、最小となる用途地域は、工業用地 : 第一種住居専用地域 2.0 メッシュ、商業用地: 第一種住居専用地域 3.6 メッシュ、農業用地: 商 業地域 13.2 メッシュ、オープンスペース用地：工業地域 22.2 メッシ 工、公共用地: 第一種住居専用地域 6.6 メッシュ、住宅用地: 工業専用 2.7 メッシュ、その他 : 第二種住居専用地域 5.0 メッシュである。

同様に、1984 年では、（最大）工業用地：工業専用地域 281.1 メッ シュ、商業用地: 商業地域 334.7 メッシュ、農業用地 : 工業専用地域 12,541.9 メッシュ、オープンスペース用地:準工業地域 384.3メッシュ、 公共用地:準工業地域 109.3 メッシュ、住宅用地:近隣商業地域 4,332.0 メッシュ、その他：工業専用地域 12.8 メッシュ。

（最小）工業用地: 第一種住居専用地域 2.7 メッシュ、商業用地: 第 一種住居専用地域 2.8 メッシュ、農業用地 : 第二種住居専用地域 6,449.7 メッシュ、オープンスペース用地: 工業地域 60.8 メッシュ、公 共用地 : 第一種住居専用地域 6.4 メッシュ、住宅用地: 工業専用地域 26.0 メッシュ、その他:第一種住居専用地域 6.1 メッシュであった。こ のように、土地利用用途ごとの最大・最小クラスターとなる用途地域は 異なっており、傾向がつかみにくい。

Tab.2 に、1994 年及び 1984 年の各用途地域における土地利用クラスタ 一の大きさの変化率を示した。全用途·全域でみると、1984年が平均 3,854 メッシュなのに対し、1994 年では 2,332 メッシュと $39 \%$ 減少している。 
Tab.1 Averaged Size of ALU Clusters in ODL

\begin{tabular}{|c|c|c|c|c|c|c|c|c|c|}
\hline & & Industrial & Commercial & Agriculture & os & PublicUse & Residential & Other & All Types \\
\hline \multirow{2}{*}{ EDR1 } & 1994 & 2.0 & $\overline{3.6}$ & 229.3 & 78.9 & $\overline{6.6}$ & $4,054.9$ & 6.8 & $\overline{2,819.6}$ \\
\hline & 1984 & 2.7 & 2.8 & $8,649.0$ & 122.5 & 6.4 & $3,944.3$ & 6.1 & $4,542.1$ \\
\hline \multirow{2}{*}{ EDR2 } & 1994 & 2.0 & 10.2 & 826.5 & 81.0 & 14.9 & $3,341.9$ & 5.0 & $1,928.1$ \\
\hline & 1984 & 3.4 & 8.1 & $6,449.7$ & 160.5 & 17.0 & $3,194.0$ & 8.5 & $2,437.9$ \\
\hline \multirow{2}{*}{ RD } & 1994 & 24.2 & 25.5 & $1,567.5$ & 56.3 & 11.2 & $2,376.6$ & 11.3 & $1,291.2$ \\
\hline & 1984 & 11.1 & 20.5 & $10,137.5$ & 168.7 & 10.2 & $2,170.5$ & 10.5 & $2,555.5$ \\
\hline \multirow{2}{*}{$\mathrm{NC}$} & 1994 & 7.5 & 60.4 & 59.9 & 86.7 & 8.3 & $4,585.5$ & 5.9 & $2,175.5$ \\
\hline & 1984 & 17.2 & 60.3 & $9,638.6$ & 349.6 & 16.5 & $4,332.0$ & 8.6 & $2,508.2$ \\
\hline \multirow{2}{*}{$\mathrm{CD}$} & 1994 & 7.2 & 320.1 & 13.2 & 52.0 & 18.9 & $2,673.0$ & 7.3 & 413.0 \\
\hline & 1984 & 17.3 & 334.7 & $9,805.9$ & 243.7 & 17.9 & $2,138.6$ & 9.6 & 603.7 \\
\hline \multirow[b]{2}{*}{ LI } & 1994 & 13.9 & 43.9 & 986.1 & 41.6 & 157.7 & $1,343.5$ & 9.0 & 381.3 \\
\hline & 1984 & 23.1 & 27.6 & $10,906.8$ & 384.3 & 109.3 & $1,292.8$ & 8.6 & 797.4 \\
\hline \multirow{2}{*}{ ID } & 1994 & 46.4 & 34.5 & $5,275.1$ & 22.2 & 23.0 & 469.8 & 8.9 & 176.7 \\
\hline & 1984 & 45.1 & 17.3 & $11,847.3$ & 60.8 & 22.7 & 280.8 & 7.3 & 617.6 \\
\hline \multirow{2}{*}{ EDI } & 1994 & 431.5 & 22.8 & $1,094.8$ & 55.5 & 56.9 & 2.7 & 15.2 & 289.8 \\
\hline & 1984 & 281.1 & 17.4 & $12,541.9$ & 288.7 & 45.2 & 26.0 & 12.8 & $1,132.7$ \\
\hline \multirow{2}{*}{ UCA } & 1994 & 192.3 & 12.1 & $9,678.6$ & 119.2 & 194.5 & 131.8 & 9.2 & $6,191.4$ \\
\hline & 1984 & 154.1 & 11.3 & $14,877.0$ & 138.4 & 20.5 & 25.9 & 7.7 & $10,648.3$ \\
\hline \multirow{2}{*}{ All Type } & 1994 & 267.0 & 139.0 & $7,446.0$ & 79.0 & 62.0 & $3,059.0$ & 9.0 & $2,332.0$ \\
\hline & 1984 & 151.0 & 154.0 & $12,232.0$ & 200.0 & 37.0 & $2,833.0$ & 9.0 & $3,854.0$ \\
\hline
\end{tabular}

Tab. 2 Rate of Change

\begin{tabular}{||l|l|l|l|l|l|l|l|l|l|l} 
Industrial & Commercial & Agriculture & OS & PublicUse & Residential & Other & All Types \\
\hline
\end{tabular}

\begin{tabular}{|c|c|c|c|c|c|c|c|c|c|}
\hline & & & & & & & & & \\
\hline \multirow{2}{*}{ EDR1 } & Rate(\%) & $\Delta 0.24$ & 0.22 & $\Delta 0.73$ & $\Delta 0.36$ & 0.03 & 0.03 & 0.10 & $\Delta 0.38$ \\
\hline & Value(M) & $\Delta 0.64$ & 0.81 & $\Delta 6,352.70$ & A 43.59 & 0.20 & 110.62 & 0.65 & $\Delta 1,722.49$ \\
\hline \multirow{2}{*}{ EDR2 } & Rate(\%) & $\Delta 0.40$ & 0.21 & $\Delta 0.87$ & $\triangle 0.50$ & $\Delta 0.13$ & 0.04 & $\Delta 0.41$ & $\Delta 0.21$ \\
\hline & Value(M) & $\Delta 1.35$ & 2.11 & $\Delta 5,623.13$ & $\Delta 79.56$ & $\Delta 2.14$ & 147.94 & $\Delta 3.48$ & $\Delta 509.80$ \\
\hline \multirow{2}{*}{$\mathrm{RD}$} & Rate(\%) & 0.54 & 0.20 & $\Delta 0.85$ & 0.67 & 0.09 & 0.09 & 0.07 & $\Delta 0.49$ \\
\hline & Value(M) & 13.10 & 5.08 & $\Delta 8,570.07$ & $\Delta 112.38$ & 1.00 & 206.12 & 0.77 & $\Delta 1,264.26$ \\
\hline \multirow{2}{*}{ NC } & \begin{tabular}{|l|} 
Rate $(\%)$ \\
\end{tabular} & $\Delta 0.56$ & $\Delta 0.00$ & $\Delta 0.99$ & $\Delta 0.75$ & $\Delta 0.50$ & $\Delta 0.06$ & $\Delta 0.32$ & $\triangle 0.13$ \\
\hline & Value(M) & $\Delta 9.67$ & 0.12 & $\Delta 9,578.69$ & $\Delta 262.93$ & $\Delta 8.21$ & 253.52 & $\Delta 2.71$ & $\Delta 332.69$ \\
\hline \multirow{2}{*}{ CD } & Rate $(\%)$ & $\Delta 0.58$ & $\Delta 0.04$ & $\Delta 1.00$ & $\Delta 0.79$ & $\Delta 0.05$ & $\Delta 0.20$ & $\Delta 0.24$ & $\Delta 0.32$ \\
\hline & Value(M) & $\Delta 10.05$ & $\Delta 14.59$ & $\Delta 9,792.72$ & $\Delta 191.76$ & 0.99 & 534.40 & $\Delta 2.32$ & $\Delta 190.70$ \\
\hline \multirow{2}{*}{ LI } & Rate(\%) & $\Delta 0.40$ & 0.37 & $\Delta 0.91$ & $\Delta 0.89$ & 0.31 & 0.04 & 0.04 & $\Delta 0.52$ \\
\hline & Value(M) & $\Delta 9.26$ & 16.34 & A $9,920.66$ & $\Delta 342.72$ & 48.38 & 50.69 & 0.37 & $\Delta 416.17$ \\
\hline \multirow{2}{*}{ ID } & Rate(\%) & 0.03 & 0.50 & $\Delta 0.55$ & $\Delta 0.64$ & 0.01 & 0.40 & 0.17 & $\Delta 0.71$ \\
\hline & Value(M) & 1.34 & 17.15 & $\Delta 6,572.24$ & $\Delta 38.63$ & 0.30 & 189.05 & 1.54 & $\Delta 440.86$ \\
\hline \multirow{2}{*}{ EDI } & Rate(\%) & 0.35 & 0.24 & $\Delta 0.91$ & $\Delta 0.81$ & 0.21 & $\Delta 0.90$ & $\Delta 0.16$ & $\Delta 0.74$ \\
\hline & Value(M) & 150.36 & 5.40 & A $11,447.16$ & $\Delta 233.16$ & 11.68 & $\Delta 23.35$ & 2.36 & $\Delta 842.84$ \\
\hline \multirow{2}{*}{ UCA } & Rate(\%) & 0.20 & 0.07 & $\Delta 0.35$ & $\Delta 0.14$ & 0.89 & 0.80 & 0.16 & $\Delta 0.42$ \\
\hline & Value(M) & 38.18 & 0.90 & A $5,198.36$ & $\Delta 19.21$ & 174.03 & 105.89 & 1.49 & $\Delta 4,456.89$ \\
\hline \multirow{2}{*}{ All Type } & Rate(\%) & $\Delta 0.43$ & $\Delta 0.10$ & $\Delta 0.39$ & $\Delta 0.61$ & $\Delta 0.41$ & $\Delta 0.07$ & - & $\triangle 0.39$ \\
\hline & $\mid$ Value(M) $\mid$ & 115.74 & $\Delta 15.70$ & $\Delta 4,786.14$ & $\Delta 121.27$ & 25.36 & 226.64 & $\Delta 0.65$ & $\Delta 1,522.27$ \\
\hline
\end{tabular}

また、1984 年と 1994 年において著しい変化が見られた用途地域は、 工業用地：商業地域 $58 \%$ (減)、商業用地：工業地帯 $50 \%$ (増)、農業 用地:商業地域 $99.9 \%$ (減)、オープンスペース用地:準工業地域 $89 \%$

(減)、公共用地: 近隣商業地域 $50 \%$ （減）、住宅用地：工業専用地域 90\%（減）、その他：第二種住居専用地域 $41 \%$ (減)であった。

全体的に、全用途・全域と同様に減少しており、小クラスター化の傾 向にあるといえる。しかし、住居地域、工業地域、市街化調整区域では、 ほぼ全用途が大クラスター化している。このように、全体としては沿岸 域の土地利用クラスターは、小規模化の傾向にあることが把握できた。 また、用途地域の種類として地域指定が行なわれていない地域と市街化 調整区域外があるが、規模の大小や数の把握においては判断基準となら ない為、除外した。

Tab.1 より、土地利用クラスターの大きさの平均値が、1994 年で一番 小さかったのは準工業地帯の 381.3 メッシュであった。しかし、1984 年 から 1994 年の 10 年間での用途地域別の変化率をみると、工業専用地域
の土地利用クラスターの隇少率が $74 \%$ 一番大きい。建築基準法第 27 条及び第 47 条関連別表第二 (ぬ) 項から、準工業地域は他の用途地域よ りも比較的用途規制が緩やかであるため準工業地域内の土地利用の変動 が顕著に表れると考えられ、準工業地域の変化率が最も大きくなると推 測される。しかし、結果として、変化率が最も著しかった地域は、工業 専用地域であった。変化率が著しい用途地域と、大きさの平均の最小值 をとる用途地域が一致しないことは、用途地域内の用途の違い以外にも 要因があるといえる。土地利用クラスターは、用途地域の用途の違いよ りも他の要因に規定されると考えられる。

\section{4-2. 用途地域クラスターの大きさと土地利用クラスターの大きさ (メッ シュ単位) の関係}

Fig.7-1〜Fig.7-9は、用途地域クラスターの大きさと土地利用クラスタ 一の大きさ (メッシュ単位) との関係を示したものである。オーバーレ イの際、一方をメッシュ単位にして隙間を埋めてオーバーレイさせる必 要があるが、「指定」である用途地域をクラスター単位とし、メッシュご 
とにプロットした全用途の土地利用クラスターの大きさを、用途別の用 途地域クラスター単位で平均化した。

グラフでは大きさが 1〜100 メッシュの用途地域クラスターを取り上 げている。また、Fig.8-1 Fig.8-9 の回帰曲線は、分布を最も的確に示す 2 次曲線を用いた注 6 。図中の回帰曲線を参考に観察すると、用途地域に
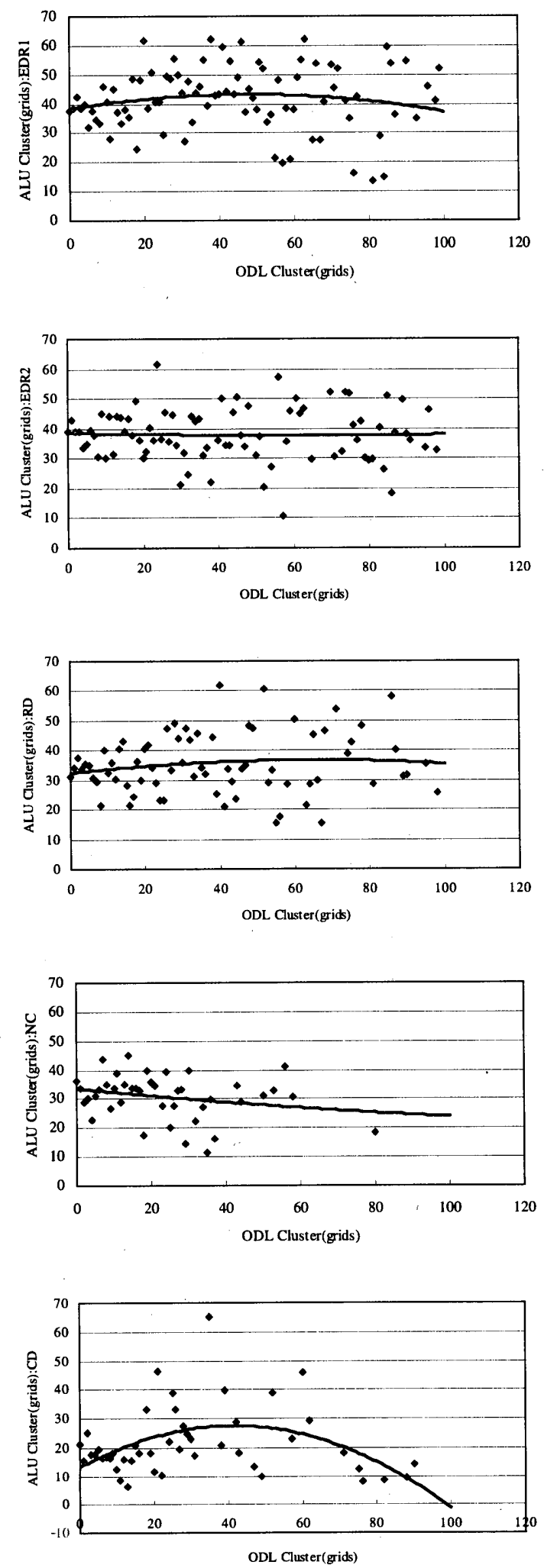

Fig.7-1 Averaged Size of ALU Clusters and Averaged Size of ODLClusters (1)
よっては、用途地域の大きさの大小によって土地利用クラスターの変動 の傾向が観察されるので、ここで、用途地域クラスターが大きいほど土 地利用クラスターが大きなものを Type I 、用途地域クラスターが大き いほど、土地利用クラスターが小さなものを Type II、変化がみられな いものを Type III と三種類に分類を行う。

OType I :用途地域クラスターが大きなものほど土地利用クラスターが 大きなもの

工業専用地域及び市街化調整区域においては、用途地域クラスターが 大きいほど、土地利用クラスターは大きくなる。

工業専用地域は、用途地域クラスター8 メッシュの大きさでは土地利 用クラスターは平均 5 メッシュの大きさで、用途地域クラスターが大き くなるにつれ土地利用クラスターも大きくなり、37メッシュで土地利用 クラスターは平均 37.7 メシュとなっている。市街化調整区域は、大き さ 7 メッシュで土地利用クラスターは平均 21 メッシュをとり、38メッ
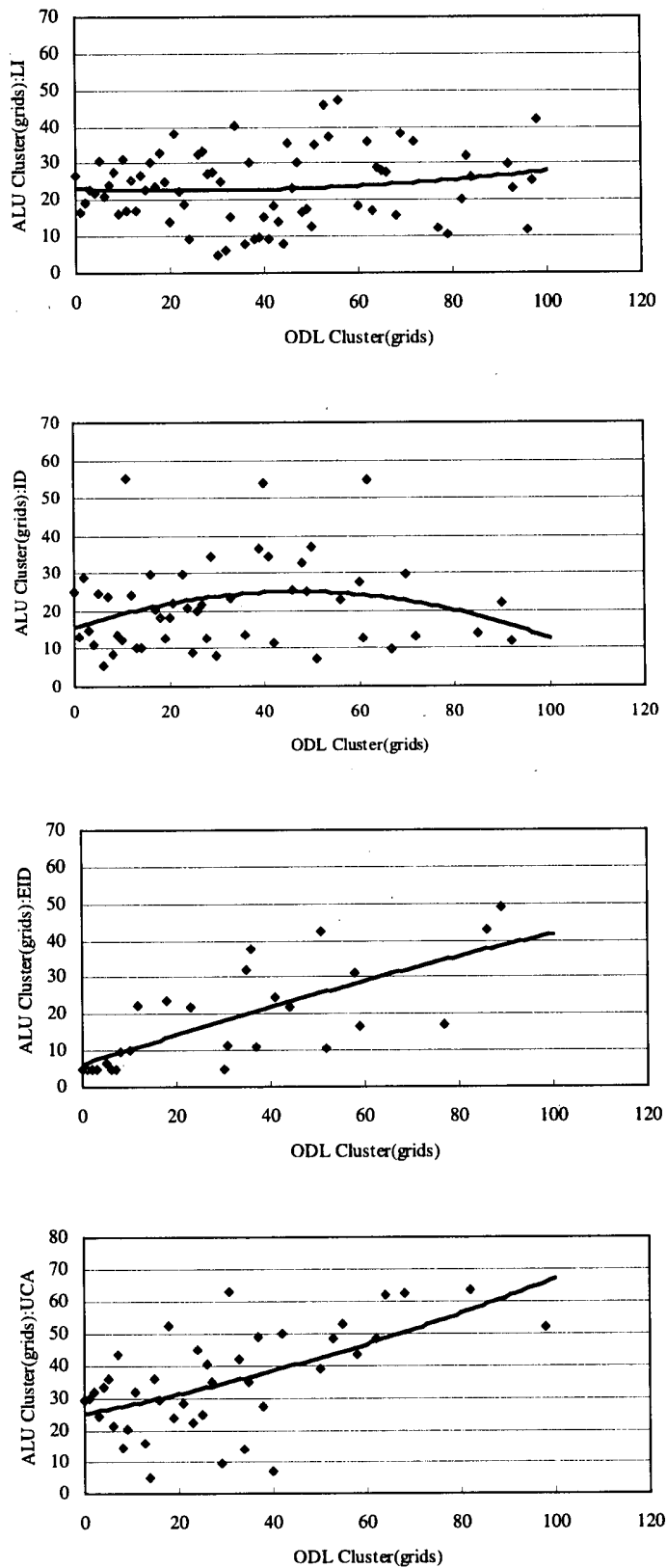

Fig.7-2 Averaged Size of ALU Clusters and Averaged Size of ODL Clusters (2) 
シュでは土地利用クラスターは平均 49 メッシュとなっている。

以上のことから、これらの用途地域では、大規模な用途地域クラスタ 一内では土地利用クラスターも大規模化していることが分かった。

OType II :用途地域クラスターが大きなものほど土地利用クラスターが 小さなもの

近隣商業地域及び商業地域は、用途地域クラスターが大きくなるにつ れて、土地利用クラスターの大きさは小さくなる結果となった。 近隣商業地域クラスターは、大きさ 7 メッシュで土地利用クラスターは 平均 33 メッシュでの大きさで、38 メッシュでは土地利用クラスターは 平均 16 メッシュの大きさとなる。商業地域は、用途地域クラスタ一の大 きさ 35 メッシュでは土地利用クラスターの大きさ平均 65 メッシュであ るが、76メッシュでは土地利用クラスターは平均 8 メッシュである。

以上、近隣商業地域及び商業地域においては、大規模なクラスター内 でも土地利用クラスターは小規模化・多数化していることがわかった。 OType III : 変化がみられないもの

第一種住居専用地域、第二種住居専用地域、住居地域、準工業地域及 び工業地域は、用途地域クラスターが大きくなっても土地利用クラスタ 一の大きさに変化はみられない。

以上、用途地域クラスターの大きさと土地利用クラスターの大きさの 関倸から、Type I 2 種、Type II 3 種、TypeIII4 種にそれぞれ分類した。こ の中で、小規模な用途地域クラスターで変動が不安定であるのは、近傍 の他用途の用途地域クラスターが影響していると考えられる。

\section{5. まとめ}

本研究で得られた知見を以下に述べる。

I . 全体的には、用途地域クラスターは臨海部で大きい。特に、住居地 域、近隣商業地域、準工業地域、工業地域及び工業専用地域で、臨 海部ほど用途地域クラスターが大きく、内陸部では小さい。ただし、 土地利用グラスターほど顕著ではなかった。

II. 全体的には、住居系の用途地域で土地利用クラスターは大規模化し ているが、土地利用用途種別でみると用途地域種別土地利用クラス ターの関係における明確な傾向はつかみにくい。

III. クラスターの大きな住居地域、近隣商業及び商業地域では土地利用 クラスターは多数化・小規模化の傾向にあり、工業地域及び市街化 調整地域では土地利用クラスターも大規模化している。

以上本稿では、大都市沿岸域における用途地域クラスターの分布状況、 用途地域の種別・クラスターの大きさによる土地利用クラスターの変動 の把握を行い、土地利用の計画的誘導の基礎資料とした。今回、研究対 象領域の特性からクラスターが大きいものが多いため、形状を加味せず に同用途のまとまりのみで評価したが、近年の臨海部での商業用地の増 加と共に土地利用はより複雑化していくことが推測され、形状を加味し たクラスターの把握の必要性は高くなってくることが考えられる。また、 相互の関係性を断定するには、(1)土地利用クラスターの経年変化と用途 地域の関係の明確化、(2)用途地域指定領域だけでなくその周辺と土地利 用クラスターとの関係の把握、(3)港湾法による臨港地区分区による指定 効果のバイアスなどこれらとの関わり等の課題を解決する必要がある。

謝辞

文部科学省及び日本大学より平成 $13 \cdot 14$ 年度私立大学等経常費補助金特別経費・ 研究科分、及び学生分の助成を受けた。

補注

1) 本用途地域メッシュデータの作成にあたっては国土交通省国土地理院において作成
された用途地域に関する細密数値情報資料を使用した。

2）土地利用については、国土地理院から提供される細密数值情報を下表に示すよう統 合して使用した。

\begin{tabular}{|c|c|c|c|c|}
\hline \multirow{2}{*}{\begin{tabular}{|c|} 
本研究での \\
適用分類 \\
\end{tabular}} & \multirow{2}{*}{$=-\kappa$} & \multicolumn{3}{|c|}{ 細密数值情報による土地利用分類 } \\
\hline & & 大分類 & 中分類 & 小分類 \\
\hline \multirow{3}{*}{ 農業用地 } & 01 & \multirow{3}{*}{$\begin{array}{c}\text { 山林· } \\
\text { 農地など }\end{array}$} & \multicolumn{2}{|c|}{ 山林·荒地など } \\
\hline & 02 & & 農地 & 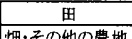 \\
\hline & & & 辰地 & 畑·その他の農地 \\
\hline \multirow{2}{*}{ 末利用地 } & 04 & \multirow{2}{*}{ 造成地 } & \multicolumn{2}{|c|}{ 造成中地. } \\
\hline & 05 & & \multicolumn{2}{|c|}{ 空地 } \\
\hline 工業用地 & 06 & \multirow{5}{*}{ 宅地 } & \multicolumn{2}{|c|}{ 工業用地 } \\
\hline \multirow{3}{*}{ 住宅用地 } & 07 & & \multirow{3}{*}{ 住宅地 } & 一般低層住宅地 \\
\hline & 08 & & & 密集低層住宅地 \\
\hline & 09 & & & \begin{tabular}{|l|l|} 
中高層往宅地 \\
\end{tabular} \\
\hline 商業用地 & 10 & & \multicolumn{2}{|c|}{ 商業·業務用地 } \\
\hline zo他 & 11 & \multirow{3}{*}{$\begin{array}{l}\text { 公共公益 } \\
\text { 施設用地 }\end{array}$} & \multicolumn{2}{|c|}{ 道路用地 } \\
\hline 公園·粶地 & 12 & & \multicolumn{2}{|c|}{ 公圈·緑地等 } \\
\hline 公共用地 & 13 & & \multicolumn{2}{|c|}{ その他の公共公㚇施設 } \\
\hline \multirow{3}{*}{ 河川·海 } & 14 & \multicolumn{3}{|c|}{ 河川・湖沿 } \\
\hline & 15 & \multirow{2}{*}{\multicolumn{3}{|c|}{ その他 }} \\
\hline & 16 & & & \\
\hline & 17 & \\
\hline
\end{tabular}

3）実在の土地利用地図からラスター型メッシュデータへの正規化の際、多少の䛠差が 生じる。幅 $100 \mathrm{~m}$ 以内の細長い部分があるものは、メッシュデータ上では 2 つのク ラスターに分離して示される場合がある。

4) 回帰曲線は、いくつかの変数に基づいて, 別の変数を予測し、右辺が合成変数 の形をとる式により表される曲線（直線）を指し、y $=b+c_{1} x+c_{2} x^{2}+c_{3} x^{3}+\cdots+c_{6} x^{6}$ (b, $c_{1} \cdots c_{6}$ : 定数) の多項式近似を用いて求められる。本研究では、 $y=b+c_{1} x+c_{2} x^{2}$ の 2 次式を用いて回帰曲線を示した。一般に、どの種の回帰式を当てはめるかは、 その分布を最も当てはまる式を用いればよいとされている。

\section{参考文献}

1）宮崎隆昌、中澤公伯 : 大都市沿岸域における土地利用上の環境評価システムに関す る基礎的研究一京浜・京葉臨海工業地帯における土地利用混合度について一、環境 情報科学論文集、第 12 号、pp119-124、1998

2）宮崎隆昌、中澤公伯: 東京湾臨海部における土地利用の総体的把握と分析システム の構築、日本建築学会技術報告集、第9号、pp.213-218、1999

3）宮崎隆昌、板本守正、中澤公伯 : メッシュデータによる土地利用異用途間距離の算 定とその性質、日本建築学会計画系論文集第 539 号、pp.171-178、2001.1

4）宮崎隆昌、横堀純子、中澤公伯 : メッシュデータによる東京湾臨海部・土地利用ク ラスター特性と変遷に関する研究、日本沿岸域学会論文集、第 15 号、pp.171-182、 2003.3

5）小出治 : 土地利用混合度の適用並びにその検定、日本都市計画学会学術研究論 文集、第 12 号、pp.79-84、1977

6）玉川英則 : :土地利用の秩序性の数理的表現に関する考察、日本都市計画学会学 術研究論文集、第 17 号、pp.73-78、1982

7）青木義次: メッシュデータ解析の一方法としての空間相関分析法ーその 1 メッシ ユデー夕解析の問題点と空間相関分析方法の理論、日本建築学会計画系論文報告集、 第 364 号、pp.94-101、1986.6

8）青木義次 : メッシュデー夕解析の一方法としての空間相関分析法の提案、土地利用 の連担性·共存性·排斥性の計量化への応用、日本建築学会計画系論文集第 368 号、 pp.119-125、1986.10

9) 青木義次、大佛俊泰 : 空間相関関数とその統計的検定の実用的計算手法と視覚化一 実用的メッシュデー夕解析システム構築のための空閒相関分析法の体系化 その 1、日本建築学会計画系論文報告集、第 416 号、pp.45-53、1990.10

10）文泰憲、他 2 名: 土地利用混合度指標に関する研究、日本都市計画学会学術研究

- 論文集、第26 号、pp.505-510、1991

11）恒川篤史、李東根、米林聡、井出久登: 土地利用混在の定量化手法、環境情報科 学、 20 巻 2 号、pp115-120、1991

12）竹内和彦、恒川篤史 : 環境資源と情報システム、古今書院、1994

13）吉川徹 : メッシュデータに立脚した土地利用の集塊性の把握手法について、日 本建築学会計画系論文集第 495 号、pp.147-154、1997.5

14）吉川徹 : メッシュデータに立脚した同種・異種土地利用の集塊性の把握手法、 日本建築学会計画系論文集第 520 号、pp.227-232、1999.6

15）玉川英則 : 土地利用パターンシュミレーションモテルの複合化とそのインプリ ケーション、日本都市計画学会学術研究論文集、第 35 号、pp.1039-1044、2000.10

16）小林祐司、佐藤誠治、姫野由香：都市における緑地分布変化の要因分析一北九 州市における緑地環境指標による変化要因について一、日本都市計画学会学術 論文集、第 36 号、pp.823-828、2001.10

17）小林祐司、佐藤誠治、姫野由香 : 緑地地域の特性把握と地域類型化に関する研 究、日本都市計画学会学術論文集、第 554 号、pp.227-234、2002.4

18）吉川徹、田中利幸 : 小規模対象地域における同変率の挙動一メッシュデータに立 脚した土地利用の集塊性の把握手法 その 3 -、日本建築学会計画系論文集第 556 号、pp.273-278、2002.6

19）飯塚祐介、吉川徹、青木義次 : 自己相関の距離聥減と方向変動に着目した分析、 日本建築学会計画系論文集、第 559 号、pp.227-232、2002.9

20）桜井慎一、横内憲久、風見正三、鈴木洋：湾岸都市におけるグレーソーンおよ び衰退地区の検出、第 23 回日本都市計画学会学術研究論文集、pp73-78

21）市古太郎、中村一樹、玉川英則 : 96 年用途地域見直し時の土地利用実態からみ た新制度運用の特性 GIS データによる都内 4 区の分析、都市計画 223、pp57-65

22）安西友子、横内憲久、桜井慎一：臨港地区の土地利用転換に伴う新たな都市計 画制度について、第 33 回都市計画学会学術研究墖文集、pp289-294

(2003年 5 月 10 日原稿受理, 2003 年 9 月 4 日採用決定) 